\title{
LARVAE AND POST-LARVAE OF PENAEIDAE AND PALAEMONIDAE IN COASTAL LAGOONS OF THE NORTH OF RIO DE JANEIRO (MACAÉ, RJ)
}

\author{
ALBERTONI, E. F., PALMA-SILVA, C. and ESTEVES, F. A. \\ Laboratório de Limnologia, Departamento de Ecologia, Universidade Federal do Rio de Janeiro, \\ Ilha do Fundão, CEP 21940-590, Rio de Janeiro, RJ, Brasil \\ Correspondence to: Edélti F. Albertoni, Laboratório de Limnologia, Departamento de Ecologia, Universidade Federal \\ do Rio de Janeiro, Ilha do Fundão, CEP 21940-590, Rio de Janeiro, RJ, Brazil, e-mail: edelti@biologia.ufrj.br \\ Received November 11, 1997 - Accepted June 29, 1998 - Distributed February 23, 1999
}

(With 5 figures)

\begin{abstract}
The northern part of the state of Rio de Janeiro shelters many coastal lagoons, located, mostly, in the "restinga" strip that stretches from the municipality of Macaé to the municipality of Quissamã. During 1995 and 1996 samplings were made aiming to verify the diversity and density of Natantia larvae in the Imboassica, Cabiúnas and Comprida lagoons. The monthly samples were taken with a $500 \mu$ net, in horizontal drags from a boat. In Comprida lagoon no larvae of any family of these crustaceans were found. In Cabiúnas lagoon, the autumn was the season of the year with greatest relative abundance, the larvae belonging to only one genus: Macrobrachium. In Imboassica Lagoon samples were taken in two situations related to the variation of the water level and contact with sea water: horizontal boat dragging when the sandbar (the strip of sand that separates the lagoon from the sea) was closed, larvae of Macrobrachium sp. being found, and no seasonal variation being detected, and horizontal manual dragging with open and closed sandbar conditions, in a region close to the sandbar. With the sandbar open, larvae and post-larvae of Penaeus paulensis and P. brasiliensis were found, the greatest abundances being found in the months of April/96 and May/95.
\end{abstract}

Key words: coastal lagoons, larvae, Penaeidae, Palaemonidae, Crustacea, distribution.

\section{RESUMO}

\section{Larvas e pós-larvas de Penaeidae e Palaemonidae em lagoas costeiras do norte fluminense (Macaé, RJ)}

A região norte do estado do Rio de Janeiro abriga uma série de lagoas costeiras, localizadas, em sua maioria, na região da restinga que se estende do município de Macaé ao município de Quissamã. Durante 1995 e 1996 foram realizadas coletas com o objetivo de verificar a diversidade e densidade de larvas de Natantia nas lagoas Imboassica, Cabiúnas e Comprida. As coletas mensais foram realizadas com rede de $500 \mu \mathrm{em}$ arrastos horizontais com barco. Na lagoa Comprida não foram encontradas larvas de nenhuma família destes crustáceos. Na lagoa Cabiúnas, o outono foi a estação do ano com maior abundância relativa, sendo as larvas pertencentes a um único gênero: Macrobrachium. Na lagoa Imboassica foram realizadas coletas em duas situações em relação à variação do nível d'água e contato com o mar: arrastos horizontais de barco com a barra (faixa de areia que separa a lagoa do mar) fechada, sendo encontradas larvas de Macrobrachium sp, não se encontrando diferença em relação à estação do ano, e arrastos horizontais manuais, com barra fechada e aberta, na região próxima à barra da lagoa. Com a barra aberta, foram coletadas larvas e pós-larvas de Penaeus paulensis e P. brasiliensis, sendo as maiores abundâncias registradas nos meses de abril/96 e maio/95.

Palavras-chave: lagoa costeira, larvas, Penaeidae, Palaemonidae, Crustacea, distribuição. 


\section{INTRODUCTION}

The coastal lagoons are characterized by exhibiting a high biodiversity, being environments strongly influenced by the ocean, that are commonly found separated from it by thin sandbars (Barnes, 1980). Among the most frequent communities in these environments, the crustaceans are outstanding, and may reach a sizeable animal biomass (Bond-Buckup \& Buckup, 1989; D'Incao, 1991; among others). Although of great importance in the secondary production of the coastal lagoons, the crustaceans are still little studied.

The species of the genus Macrobrachium are usually found in fresh water, and many young stages are also captured in brackish or salt water, especially in subtropical and tropical regions (Holthuis, 1980). Most species of this genus lay down their eggs in brackish water, and adults and larvae need the salinity to finish their reproductive cycle (Boschi, 1974).

Studies about different ecological and biological aspects of many species have been conducted in various parts of Brazil, being outstanding among them Gomes-Correa (1977), Bond \& Buckup (1982), Lobão et al., (1986), Bond-Buckup \& Buckup (1989), Müller \& Prazeres (1992), Moreira \& Odinetz-Collart (1993) and Fonseca (1995).
The species of the genus Penaeus, on the other side, present a life cycle that involves migrations of the post-larval stages to estuarine regions, where they stay during their juvenile growth, returning to the ocean for sexual maturation and reproduction. Many works regarding quantification of post-larvae have been done in some regions of Brazil where these crustaceans represent a fishing resource rather well explored (Brisson, 1977, 1981; D'Incao, 1991; Chagas-Soares et al., 1995; among others).

This research aims to provide information about the ocurrence of larvae and post-larvae of Penaeidae and Palaemonidae in three coastal lagoons of the northern coast of the state of Rio de Janeiro, under different physical and chemical conditions and different impacts of anthropic order, and in this way to contribute to the knowledge of crustaceans in these environments.

\section{STUDY AREA}

The northern region of the state of Rio de Janeiro is home to a series of coastal lagoons, most of them located in the "restinga" strip that stretches between the municipalities of Macaé $\left(22^{\circ} 50^{\prime} \mathrm{S}\right.$; $\left.44^{\circ} 42^{\prime} \mathrm{W}\right)$ and Quissamã $\left(22^{\circ} 12^{\prime} \mathrm{S}\right.$; 4 $\left.41^{\circ} 35^{\prime} \mathrm{W}\right)$ (Fig. 1). Some of these lagoons are strongly impacted

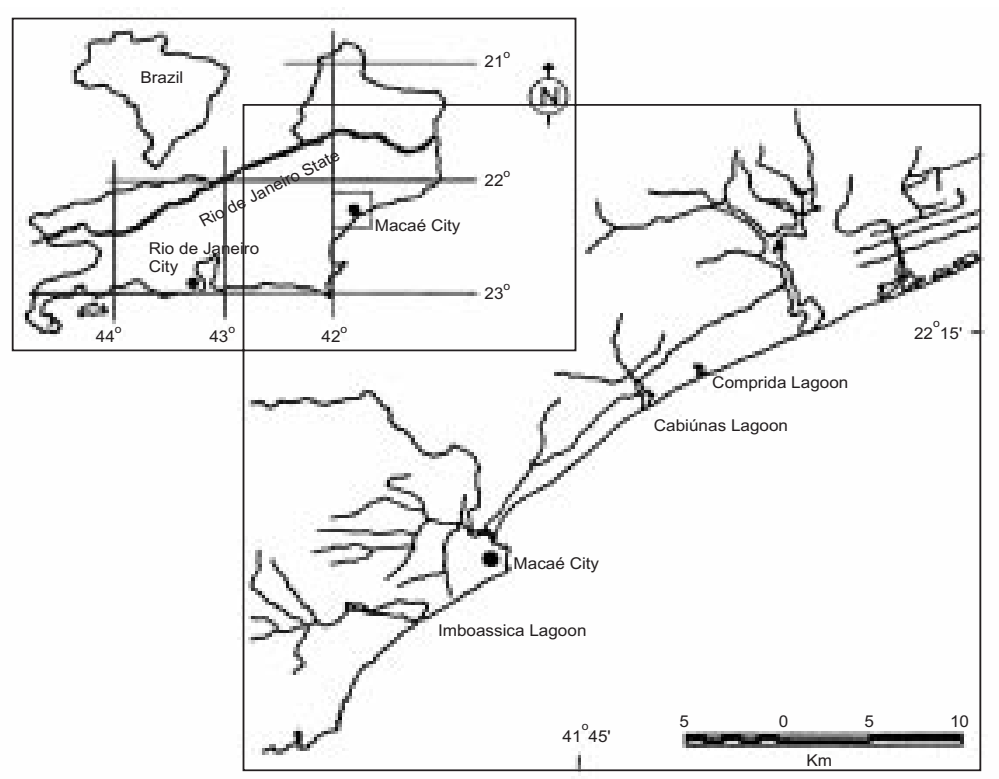

Fig. 1 - Study area. 
by anthropic action, while others are reasonably well preserved. Cabiúnas and Comprida lagoons are situated in the "restinga" complex, not showing any relevant anthropic impact and being classified as well preserved natural ecosystems.

Cabiúnas and Comprida lagoon have areas of $0.35 \mathrm{~km}^{2}$ and $0.11 \mathrm{~km}^{2}$, respectively (Reid \& Esteves, 1984). They are freshwater lagoons, with a dark complexion, due to the humic and fulvic components of the surrounding "restinga" soils (Esteves et al., 1984).

Imboassica lagoon has an area of $3,26 \mathrm{~km}^{2}$, it is located in the urban zone of the municipality of Macaé, being an ecosystem that undergoes anthropic impacts in different ways. There is a constant and untreated sewage flow, approximately $20 \%$ of its area received landfills for land speculation and it has been submitted to frequent and aperiodic openings of the sandbar that separates it from the ocean. These impacts, especially the sandbar opening, originate profound alterations in the metabolism of this ecosystem, altering the composition and structure of its communities (Faria et al., 1994).

\section{MATERIAL AND METHODS}

Monthly samplings were done in Cabiúnas and Comprida (from April/95 to April/96) and Imboassica (from September/95 to August/96) lagoons. A conic net was utilized, with a $0.5 \mathrm{~mm}$ mesh size, in horizontal boat drags, at low speed, with a duration of five minutes for each drag. The volume of filtered water was obtained by fluxometer attached to the mouth of the net (area $=$ $0.1962 \mathrm{~m}^{2}$ ).

Also, in Imboassica lagoon, manual drags in the margin close to the lagoon's sandbar and manual drags when the sandbar was open (November/95; April/96; November/96 and January/97) were performed. The manual drags were performed by walking during five minutes, with the same net positioned along the side of the body.

In Cabiúnas and Comprida lagoons three sampling sites were established, back, middle and sandbar, areas 1, 2 and 3, respectively. During sampling the water temperature was taken with a thermometer, and the salinity was taken with an optical refractometer. All the samples were taken in the morning period. At Imboassica lagoon 4 sampling sites were established, and the samples were taken in the nocturnal period, approximately one hour after sunset.

The collected individuals were fixed with $10 \%$ formaldehyde, and the samples were later separated and identified in a stereomicroscope, and the organisms were stored in $70 \%$ alcohol. The number of larvae was standardized to a volume of $10 \mathrm{~m}^{3}$ of filtered water.

\section{RESULTS AND DISCUSSION}

\section{a) Comprida Lagoon}

In this lagoon no larvae of the families Penaeidae and Palaemonidae were registered. Probably the water characteristics, with a high content of humic and fulvic acids, which lowers the $\mathrm{pH}$ (it varies from 4.35 to 5.0), do not favor the development and growth of these crustaceans, although two species of adults were registered, Macrobrachium potiuna and Palaemon (P.) pandaliformis, by periods previous to the development of this research (Albertoni et al., in press).

Another factor that might explain no larvae in such lagoon could be the diurnal period of sampling because, according to Moreira \& OdinetzCollart (1993), Macrobrachium larvae present diel vertical migration in Amazonian lakes, and could also present this pattern in coastal lagoons. The diel cycles were not tested in this research.

\section{b) Cabiúnas Lagoon}

The spatial analysis of the results did not show any significant difference between the three areas (Kruskall-Wallis, $\mathrm{p}<0.05$ ) (Siegel, 1975), therefore the results are presented as the average number of larvae per $10 \mathrm{~m}^{3}$, compounding an estimate for the whole lagoon.

In Cabiúnas lagoon no marine species were found, and all the samples were made up of larvae of Palaemonidae, of the genus Macrobrachium, which may be attributed to the fact that this lagoon does not possess any connection with the ocean, and its sandbar is rarely opened.

The month with greatest relative abundance was May/95, decreasing significantly in the following months (Fig. 2). The larvae of Palaemonidae exhibited reduced density all year long, with the exception of the months of April/95 and May/95. A rising trend is also apparent, beginning in March/96 and April/96. The autumn period corresponds the highest larvae abundances $\left(\chi^{2}, \mathrm{p}<0.05\right)$. 
Bialetzki et al., (1997) cite for M. amazonicum the greatest captures in the spring and summer months (from September to December), in the hydrographic basin of the Paraná river, where the seasonality is more pronounced than in the present study area. Müller \& Prazeres (1992) found, for M. olfersii, in Santa Catarina, reproduction periods that encompass the autumn and the beggining of the summer, this species presenting two reproduction periods per year. Verdi (1996), working in Uruguai with $M$. borelli, found that the maximal reproduction of this species takes place during the months of the end of spring and beggining of summer.

There is no information available about the reproductive periods of Macrobrachium species for coastal environments in tropical regions, and it is believed that the seasonality is marked by small differences in water temperature and especially by dry and rainy periods. According to the data of the present research, there seems to be a time of the year (April and May) when reproduction is more intense, when ovigerous female adult specimens of Macrobrachium potiuna were collected. During the sampling period, this was the only species collected in this lagoon, although $M$. iheringi and M. acanthurus were found in previous periods (Albertoni et al., in press). Throughout the year samplings with traps which took place in various regions of the lagoon and with sieves in the marginal vegetation, but no other species was found.

The time of the reproduction and consequent abundance of larvae keeps a relationship with the water temperature (Table 1).

As may be observed in Fig. 2, the temperature curve exhibits an inverted relationship with the larvae abundance.

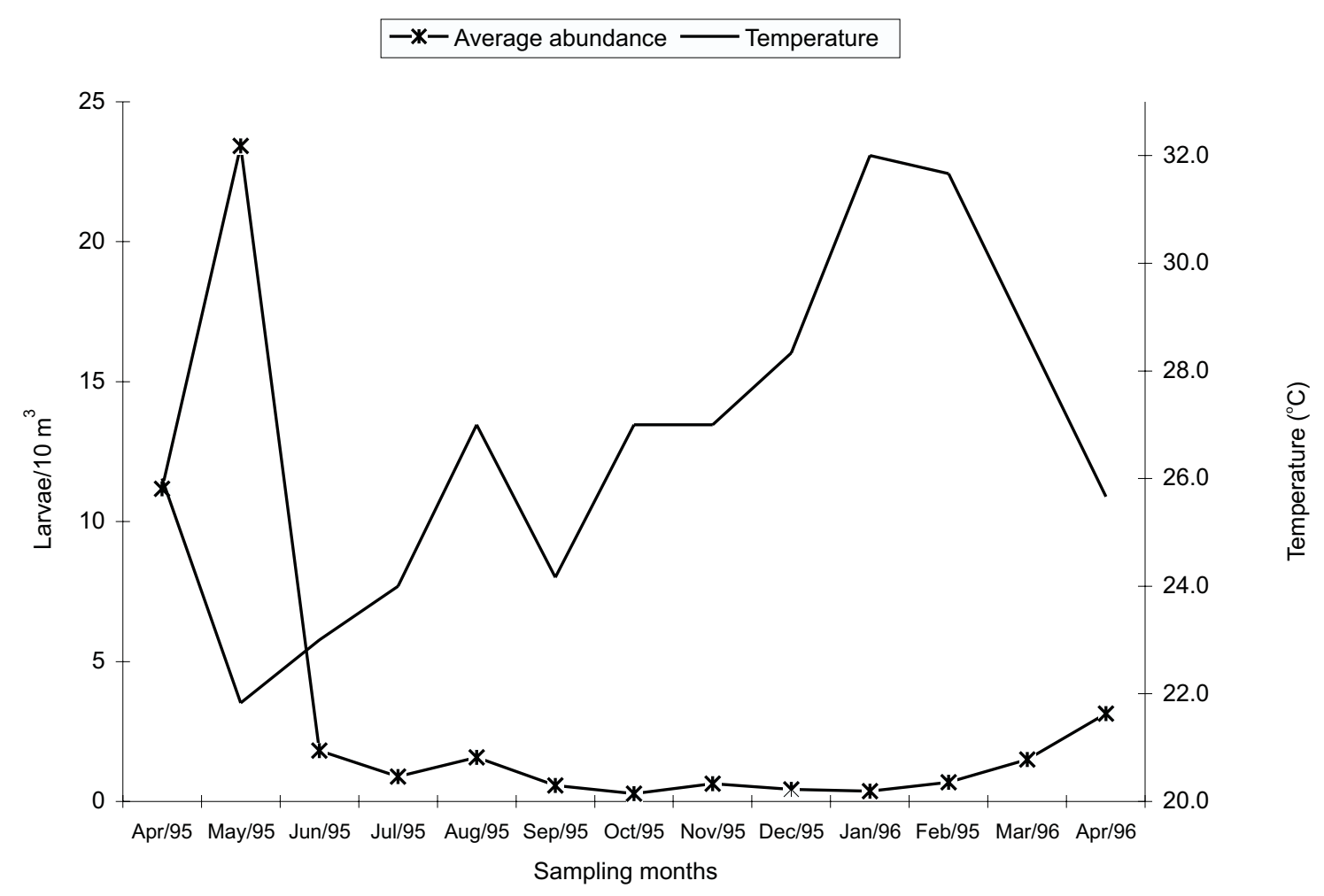

Fig. 2 - Water temperature and monthly average abundance of Macrobrachium larvae, Cabiúnas lagoon. 
TABLE 1

Larvae average abundance (LA), volume of filtered water (VF), number of larvae standardized to $10 \mathrm{~m}^{3}$ (SL), salinity (S- g/l), and temperature $\left({ }^{\circ} \mathrm{C}\right.$ ) in Cabiúnas lagoon (Macaé, $\mathrm{RJ}$ ) in the period of April/95 to April/96.

\begin{tabular}{|c|c|c|c|c|c|}
\hline Months & LA & VF & SL & S-g/l & $\mathrm{T}\left({ }^{\circ \mathrm{C}}\right)$ \\
\hline Apr/95 & 43.3 & 37.78 & 11.18 & 0.0 & 26.0 \\
\hline May/95 & 45.0 & 37.87 & 23.42 & 0.0 & 21.8 \\
\hline Jun/95 & 11.3 & 60.76 & 1.82 & 0.0 & 23.0 \\
\hline Jul/95 & 4.0 & 42.46 & 0.89 & 0.0 & 24.0 \\
\hline Aug/95 & 6.67 & 41.72 & 1.57 & 0.0 & 27.0 \\
\hline Sep/95 & 2.33 & 46.22 & 0.57 & 0.0 & 24.2 \\
\hline Oct/95 & 1.33 & 50.12 & 0.28 & 0.0 & 27.0 \\
\hline Nov/95 & 3.0 & 46.19 & 0.63 & 0.0 & 27.0 \\
\hline Dec/95 & 4.0 & 95.57 & 0.43 & 0.0 & 28.3 \\
\hline Jan/96 & 3.67 & 101.33 & 0.37 & 0.0 & 32.0 \\
\hline Fev/96 & 5.0 & 71.99 & 0.69 & 0.0 & 31.7 \\
\hline Mar/96 & 14.33 & 92.03 & 1.5 & 0.0 & 28.7 \\
\hline Apr/96 & 23.67 & 75.37 & 3.14 & 0.0 & 25.7 \\
\hline
\end{tabular}

\section{c) Imboassica Lagoon}

The spatial analysis of the results showed that there is not any significant difference in the larvae abundance between the areas (Kruskall-Wallis, $p<$ $0,05)$, therefore the results are presented as average number of larvae per $10 \mathrm{~m}^{3}$, compounding an estimate for the entire lagoon.

In the months when the lagoon remained with its sandbar closed, larvae of the genus Macrobrachium were found. Since no communication with the ocean was present in these ocasions, no larvae or post-larvae of marine species were found, as they do not reproduce in the lagoon.

A significant reduction in the abundance of larvae was verified in the periods after sandbar openings (Fig. 3). This must belong to the species Macrobrachium acanthurus, which is dominant in the lagoon. It is a species of coastal rivers, probably reaching the lagoon through the Imboassica river. It is usually found in the stands of the aquatic macrophytes Typha domingensis and Eleocharis mutata, and some ovigerous females were captured from draggings of the beach region, close to the lagoons's sandbar.

With the opening of the sandbar, the lagoon loses practically all the water from its surface, great number of aquatic macrophytes die (Silva \& Esteves, 1996; Silva et al., 1996), and fishes and crustaceans are dragged to the ocean. The shrimps that are left behind in the remaining ponds and small channels are intensively fished out.

With the reduction of the water surface, the link of Imboassica river is interrupted, salinity, temperature and $\mathrm{pH}$ are drastically altered and stands of aquatic macrophytes dry out and are burned by the inhabitants of the area. Therefore, the adult populational stock is much reduced and the result is a decrease in larvae abundance.

As a function of the aperiodicity of sandbar openings, and of the small gap of time between them, no significant difference in larvae abundance was found $\left(\chi^{2}, p<0.05\right)$ between the seasons of the year.

It is believed that, in Imboassica lagoon, the larvae abundance, and therefore, the reproductive period of Macrobrachium, has a greater relationship with the sandbar openings than with the abiotic variables, due to the almost total mortality of the adult stock when the sandbar is opened. The adult stock is dependent, mostly, on the connection with the Imboassica river, and on the increase on water level, with corresponding growth and maintenance of the aquatic macrophyte stands.

In the manual draggings made with the sandbar closed, larvae of Macrobrachium were found in various densities, according to the time of the year and to the interval between the sandbar openings (Fig. 4). 


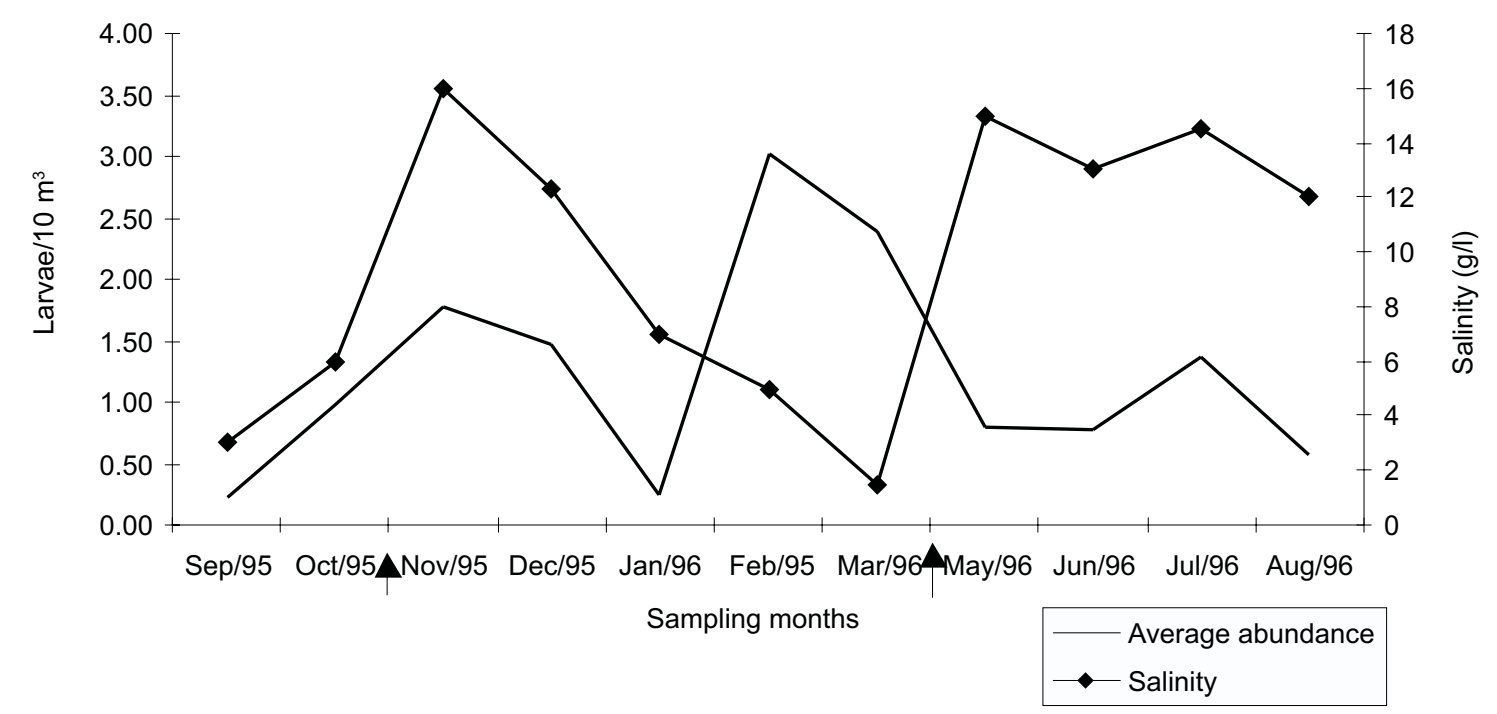

Fig. 3 - Salinity and average abundance of Macrobrachium larvae from boat drags, Imboassica lagoon. (Arrows show sandbar openings).

Macrobrachium acanthurus exhibits complete larval development in salinities ranging from 14 to $20 \mathrm{~g} / \mathrm{L}$ (Moreira et al., 1986), being classified as a coastal species, that inhabits the lower courses of rivers, migrating to the estuaries during the reproductive season (Jalihal et al., 1993). Bueno \& Rodrigues (1995) point to the genus Macrobrachium as a good example of a Palaemonidae in a process of conquest of freshwater environments, although dependent, still, of brackish water for its larval development.

Moreira (1994) mention that many Palaemonidae, among them M. acanthurus, are predominantly fresh water species, but their larvae show a metabolic relationship of salinity dependence. The author, evaluating responses of some larvae to salinity variation, considers that the reduction of the number of molts may be advantageous to species inhabiting estuarine zones, and that the osmoregulatory capacity of this species may be related to genetic characteristics, as different permeabilities in the tegument.

The samplings for evaluation of the entrance of post-larvae of Penaeus were made at the four sandbar openings that took place during the sampling period. The openings that ocurred in the autumn (April/96) were found to be better timed to the entrance of Penaeus post-larvae in the Imboassica lagoon than those ocurring in the end of spring (November/95 and November/96) and summer (January/97). In the samplings made with the sandbar open, an estimate was made of the number of larvae and post-larvae of Penaeidae that enter the lagoon for growth and development. Penaeidae larvae are captured only during this period, for as the lagoon remains open (from 8 to 15 days), it behaves as an estuary. After the closing, there is not any possibility of these organisms entering the lagoon. The collected species are Penaeus brasiliensis and P. paulensis, both commonly called "pink shrimps", which are an important fishing resource for fishermen in Imboassica lagoon. In Fig. 5, the larvae and post-larvae densities of Penaeus spp. (in $10 \mathrm{~m}^{3}$ ), in the four samplings made, are shown.

According to Brisson (1977), in the Araruama lagoon (RJ), it was found that $P$. brasiliensis and $P$. paulensis exhibit one of their reproductive peaks during the autumn and another, smaller peak, in the end of the spring, reinforcing the results of this research.

Sandbar openings, natural or artificial, are mentioned for many coastal lagoons in Rio de Janeiro State since decades past, as a way of letting in fish and marine crustacean larvae, for posterior growth and development, being processes supported by fishermen in order to increase the fishing productivity of the environments (Oliveira, 1948; Oliveira \& Krau, 1955; Oliveira et al., 1955). 


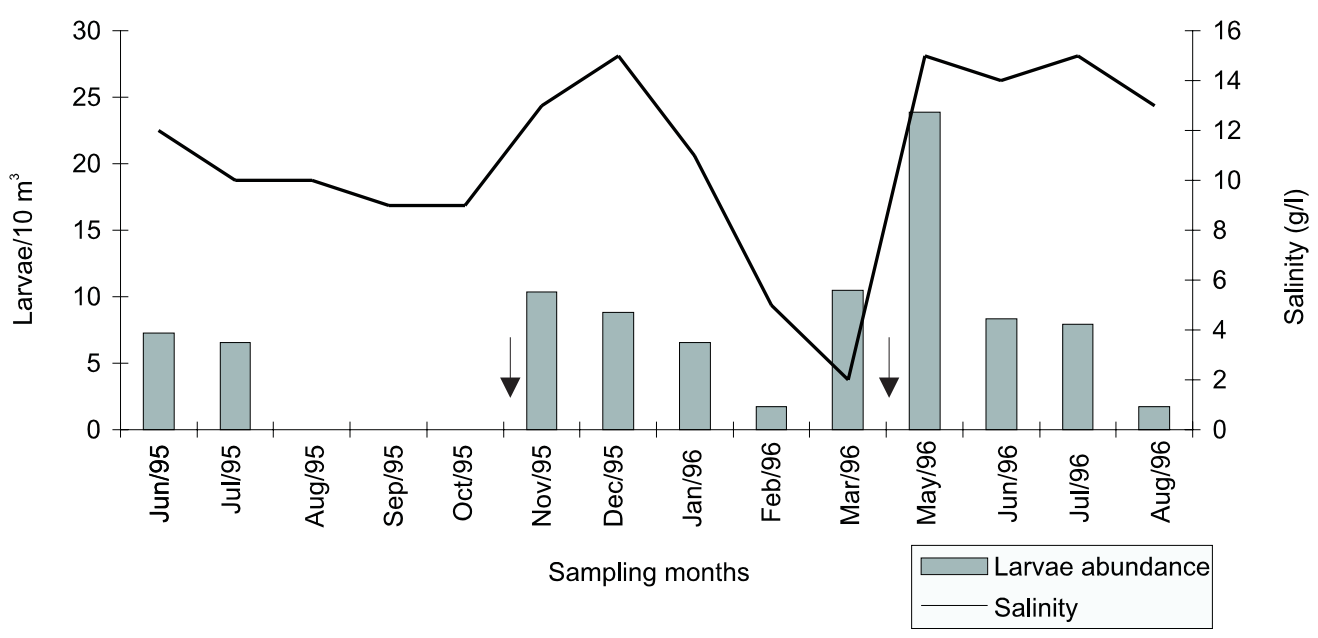

Fig. 4 - Salinity and Macrobrachium larvae abundance, sampled with manual drags with the sandbar closed, Imboassica lagoon. (Arrows show the sandbar openings.)

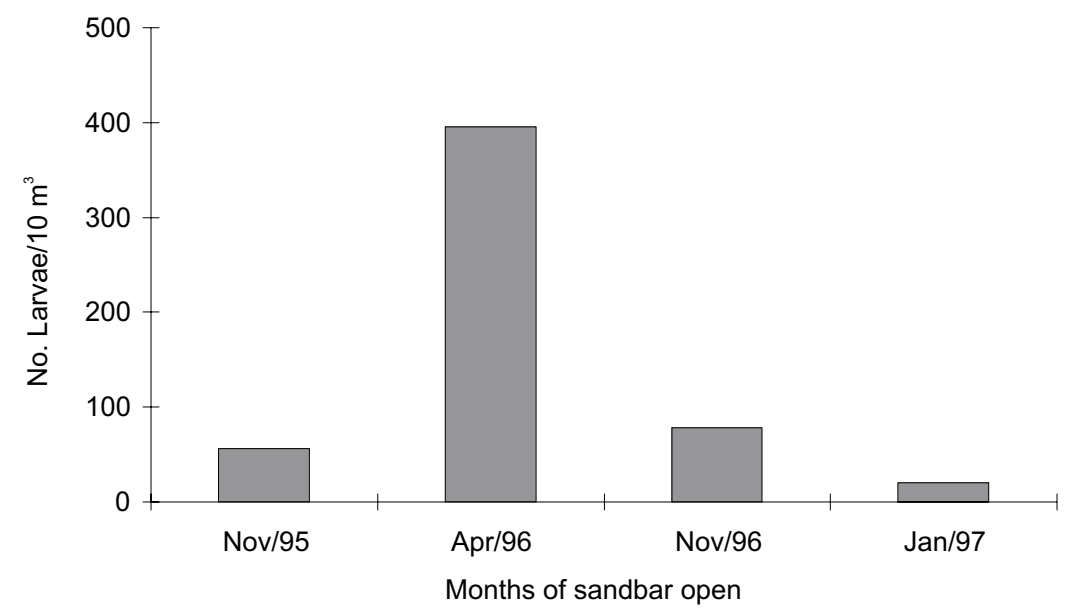

Fig. 5 - Number of Penaeidae larvae, sampled with the sandbar open, Imboassica lagoon.

In the case of Imboassica lagoon, the process of sandbar opening must take into account the reproduction season of the Penaeidae at the sea, aiming to maximize the entrance of larvae, and the reproduction season of Palaemonidae, in order to balance the populations of different species and to increase the fishing productivity.

\section{CONCLUSIONS}

The community of crustacean larvae in coastal lagoons is strongly influenced by abiotic factors. The sandbar opening, as an aperiodic phenomenon, strongly influences the composition and density of these organisms in Imboassica lagoon, for the alteration in the salinity levels caused by the inflow of seawater promotes the alternation of larvae from marine and continental species.

For the management of the process of sandbar opening in Imboassica lagoon, it is recommended that it strould be done in the autumn months, especially April and May, thus maximizing the entrance of Penaeidae larvae. In Cabiúnas lagoon, which has a practically unaltered salinity, only one genus is found, Macrobrachium, characteristic of coastal regions during reproductive seasons. 
Comprida lagoon, probably due to its low $\mathrm{pH}$, caused by the high content of humic and fulvic components, does not favor the growth and development of these crustaceans.

In order to establish the periods of the day with the greatest abundance of larvae species of the Penaeidae and Palaemonidae, we suggest investigations of diel vertical migrations in these coastal lagoons.

Acknowledgments - We thank PETROBRAS and CAPES, for the financial support; the biologists Claudio Soares, for help at the field and laboratory and Lohengrin Fernandes, for the identification of Macrobrachium larvae, and the anonimous referee for the suggestions.

\section{REFERENCES}

ALBERTONI, E. F., PALMA-SILVA, C. \& ESTEVES, F. A., Preliminary survey of Penaeidae and Palaemonidae shrimps in four tropical coastal lagoons (RJ, Brazil). Stud. Neotrop. Fauna Envir. (in press).

BARNES, R. S. K., 1980, Coastal Lagoons. Cambridge, Cambridge University Press, 106p.

BIALETZKI, A., NAKATANI, K., BAUMGARTNER, G. \& BOND-BUCKUP, G., 1997, Occurrence of Macrobrachium amazonicum (Heller, 1862) (Decapoda, Palaemonidae) in Leopold's inlet (Ressaco do Leopoldo), high Paraná river, Porto Rico, Paraná, Brazil. Rev. Brasil. Zool. (in press).

BOND, G. \& BUCKUP, L., 1982, O ciclo reprodutivo de Macrobrachium borellii (Nobili, 1896) e Macrobrachium potiuna (Müller,1880) (Crustacea, Decapoda, Palaemonidae) e suas relações com a temperatura. Rev. Brasil. Biol., 42(3):473-483.

BOND-BUCKUP, G. \& BUCKUP, L., 1989, Os Palaemonidae de águas continentais do Brasil meredional (Crustacea, Decapoda). Rev. Brasil. Biol., 49(4): 883-896.

BOSCHI, E. E., 1974, Biologia de los Crustaceos cultivables en America Latina. Carpas, 6: 1-24.

BRISSON, S., 1977, Estudo da população de peneídeos na área de Cabo Frio. II. Distribuição sazonal de post-larvas de camarão-rosa (Penaeus brasiliensis Latreille e P. paulensis Pérez-Farfante) na entrada do canal da laguna de Araruama. Cabo Frio, RJ, Publ. Inst. Pesq. Mar, 101: 1-11.

BRISSON, S., 1981, Estudo da população de peneídeos na área de Cabo Frio. IV. Limite de penetração das póslarvas de camarões-rosa na Laguna de Araruama. Cabo Frio, RJ., Publ. Inst. Pesq. Mar., 141: 1-11.

BUENO, S. L. S. \& RODRIGUES, S. A., 1995, Abbreviated larval development of the freshwater prawn, Macrobrachium iheringi (Ortmann,1897) (Decapoda, Palaemonidae), reared in laboratory. Crustaceana, 68(6): 665-686.
CHAGAS-SOARES, F., PEREIRA, O. M. \& SANTOS, E. P., 1995, Contribuição ao ciclo biológico de Penaeus schmitti (Burkenroad,1936), Penaeus brasiliensis (Latreille, 1817) e Penaeus paulensis (Pérez-Farfante, 1967), na região lagunar-estuarina de Cananéia, São Paulo, Brasil. B. Inst. Pesca, 22(1): 49-59.

D'INCAO, F., 1991, Pesca e biologia de Penaeus paulensis na lagoa dos Patos, RS. Atlântica, 13(1): 159-169.

ESTEVES, F. A., ISHI, I. H. \& CAMARGO, A. F .M., 1984, Pesquisas limnológicas em 14 lagoas do litoral do estado do Rio de Janeiro. In: L. D. de Lacerda; D. S. D. de Araujo; R. Cerqueira \& B. Turcq (orgs.), Restingas: origem, estrutura, processos, CEUFF, Niterói. pp. 65-74.

FARIA, B. M., SUZUKI, M. S. \& ESTEVES, F. A., 1994, Alterações no metabolismo da lagoa Imboacica, Macaé, RJ, associadas à ocorrência de duas sucessivas aberturas artificiais de barra. II. Congresso de Ecologia do Brasil. Sociedade de Ecologia do Brasil. Londrina, PR, 5-9 dez., Resumos, 406p.

FONSECA, K. M. L., 1995, Camarões (Atyidae $e$ Palaemonidade) da rede fluvial do estado de Rio de Janeiro: sistemática e distribuição. Dissertação de Mestrado, Museu Nacional do Rio de Janeiro, UFRJ, 86p + 10 estampas.

GOMES-CORREA, M. M., 1977, Paleomonídeos do Brasil (Crustacea, Decapoda, Natantia). Dissertação de Mestrado, Museu Nacional do Rio de Janeiro, UFRJ, 164p + 28 estampas.

HOLTHUIS, L. B., 1980, Shrimps and prawns of the world. An annotated catalogue of species of interest to fisheries. FAO Fish Synop., 125: 1-261.

JALIHAL, D. R., SANKOLLI, K. N. \& SHENOY, S., 1993, Evolution of larval developmental patterns and the process of freshwaterization in the prawn genus Macrobrachium (Bate, 1868) (Decapoda, Palaemonidae). Crustaceana, 65(3): 365-376.

LOBÃO, V. L., ROJAS, N. E. T. \& VALENTI, W. C., 1986, Fecundidade e fertilidade de Macrobrachium amazonicum (Heller,1862) (Crustacea, Decapoda) em laboratório. B. Inst. Pesca, 13(2): 15-20.

MOREIRA, G. S., MCNAMARA, J. C. \& MOREIRA, P. S., 1986, The effect of salinity on the upper thermal limits of survival and metamorphosis during larval development in Macrobrachium amazonicum (Heller) (Decapoda, $\mathrm{Pa}-$ laemonidae). Crustaceana, 50(3): 231-328.

MOREIRA, G. S., 1994, Metabolic responses of some brazilian Palaemonidae larvae to salinity variation: a review. III. Simpósio de Ecossistemas da Costa Brasileira. 2-7/04/94, Serra Negra, São Paulo. Anais, 1: 342-346.

MOREIRA, L. C. \& ODINETZ-COLLART, O., 1993, Migração vertical nictemeral das larvas de Macrobrachium amazonicum num lago de várzea na Amazônia Central, Ilha do Careiro, Brasil. Amazoniana, 12(3/4): 385-398. 
MÜLLER, Y. M. R. \& PRAZERES, A. C., 1992, Influência da salinidade e temperatura da água sobre a captura de Macrobrachium olfersii (Wiegmann,1836) coletados no canal da lagoa do Peri- Florianópolis, SC. Acta Limnol. Brasil., 4: 175-183.

OLIVEIRA, L. P. H. de., 1948, Estudo Hidrobiológico das Lagoas de Piratininga e Itaipú. Mem. Inst. Oswaldo Cruz, 46(4): 673-718.

OLIVEIRA, L. P. H. de \& KRAU, L., 1955, Observações biogeográficas durante a abertura da Barra da Lagoa de Saquarema. Mem. Inst. Oswaldo Cruz, 53(2, 3 e 4): 435449.

OLIVEIRA, L. P. H. de, NASCIMENTO, R., KRAU, L. \& MIRANDA, A., 1955, Observações biogeográficas e hidrobiológicas sobre a Lagoa de Maricá. Mem. Inst. Oswaldo Cruz, 53(2, 3 e 4): 171-227.

REID, J. W. \& ESTEVES, F. A., 1984, Considerações ecológicas e biogeográficas sobre a fauna de copepodos (Crustacea) planctônicos e bentônicos de 14 lagoas costeiras do estado do Rio de Janeiro, Brasil. In: L.D. de Lacerda; D. S. D. de Araujo; R. Cerqueira \& B. Turcq (orgs.), Restingas: origem, estrutura, processos, CEUFF, Niterói, pp. 305-326.
SIEGEL, S., 1975, Estatística não-paramétrica. Rio de Janeiro, Makron Books do Brasil Ed. Ltda., 350p.

SILVA, C. P. \& ESTEVES, F. A., 1996, O efeito de uma abertura de barra da lagoa Imboacica (Macaé, RJ), sobre um estande de Typha domingensis Pers. VIII. Seminário Regional de Ecologia, UFSCar, São Carlos, SP, 12-15/ 03/96. Resumos, 431p.

SILVA, C. P., ALBERTONI, E. F. \& ESTEVES, F. A., 1996, Biomassa e produção de três macrófitas aquáticas em uma lagoa costeira do Norte Fluminense. III. Congresso de Ecologia do Brasil, UNB, Brasília, DF, 06-11/10/ 1996, Resumos, 397p.

VERDI, A. C., 1996, Ciclo anual de reproduccion del camaron dulciacuicola Macrobrachium borellii (Nobili,1896) (Crustacea, Caridea, Palaemonidae). Rev. Brasil. Biol., 56(3): 561-568. 